'attorney disqualification is not within the scope of the [public policy] exception' to the FAA. ${ }^{9}$

The law from the non-US jurisdictions reviewed by Born appears no more settled as to whether alleged conflicts of interest are for the arbitrators or the courts to decide (p. 2322). There is certainly as much value, however, in Born's identification of the grey areas of the law of arbitration, as there is in his identification of the black letter law.

Born's treatise is both comprehensive and thought provoking, and it will quickly become one of the standard texts in its field. It fulfils the hope that he would one day come forward to answer the questions left open in his prior text book.

\title{
Daniel Girsberger***
}

Extensive research has been undertaken on the practical application of arbitration nationally and internationally. While many commentaries and textbooks are to be qualified as adopting a 'how-to' approäch, there is a growing body of scientific literature on arbitration. On an international level, Gary Born's International Commercial Arbitration is an extraordinary combination of both practical experience and academic analysis. In his introduction, Born writes that he 'aspires to provide a comprehensive description and analysis of the contemporary constitutional structure, law, practice and policy of international commercial arbitration', and that he 'also endeavours to identify prescriptive solutions for the conceptual and practical challenges that confront the international arbitral process'.

These aspirations may sound Herculean and even unrealistic at first sight. Not to those who read Born's International Commercial Arbitration. In the opinion of this reviewer, there can be no doubt that Born has reached his goals, and partially even gone beyond.

As Born emphasises from the outset, the focus of his book is on international standards and practices, rather than a single national legal system. Yet, international standards have not developed out of the blue, but have been based on converging legislation and practices in important arbitration centres such as the United States, Singapore, Hong Kong, England, France and Switzerland. Legislatures and courts in contracting states around the world have looked to and relied upon one another's decisions and have formulated and progressively refined legal frameworks of national law to ensure the effective enforcement of international arbitration agreements and awards.

9 Canaan Venture Partners, $L P$ v. Salzman, 1996 WL 62658, at *3 (Conn, Sup. Ct, 28 January 1996).

*** Prof. Dr. iur., LLM Daniel Girsberger is a founding member of the Faculty of Law of the University of Lucerne (www.unilu.ch) and a tenured professor for Swiss and International Private, Business and Procedural, as well as Comparative Law. He is a member and co-founder of the Swiss Arbitration Academy and the author of numerous publications focusing primarily on international private law and arbitration including a leading textbook in the English language on international arbitration in Switzerland. He has frequently acted as arbitrator and counsel in international commercial arbitration proceedings. 
A central theme of International Commercial Arbitration is that the New York Convention and other international instruments establish a constitutional framework for the conduct of international commercial arbitration around the world. While parties and arbitral tribunals enjoy substantial autonomy in the conduct of international arbitrations, the Convention imposes important limits on the ability of states to deny effect to international arbitration agreements and arbitral awards. Born emphasises that these limitations have not always been appreciated, and are not always fully addressed in commentary, but form a critical constitutional foundation for the contemporary international arbitral process. Identifying and refining these limits is a central aspiration of Born's book and one which it achieves with particular mastery.

The lengthy 3,000 page treatise begins with a 200 page introductory overview, followed by three Parts which follow the usual structure of treatises that aspire to comprehensively analyse the phenomenon, practice and theory of international arbitration.

Part I which is devoted to the arbitration agreement, describes the legal framework, separability, the law governing international arbitration agreements, the substantive and formal rules of validity relating to such agreements, the doctrine of competence-competence, the legal effects of international arbitration agreements, the interpretation of arbitration agreements and the rules for identifying the parties to international arbitration agreements.

Part II analyses proceedings, including the legal framework applicable to such proceedings, the selection and challenge of arbitrators, the rights and duties of international arbitrators, the selection of the arbitral seat, the conduct of arbitral procedures, the production of documents and other types of disclosure, interim measures, consolidation and joinder, the selection of substantive law, confidentiality and legal representation.

Part III is devoted to the arbitral award: it describes the legal framework, form and content, correction and interpretation, the possibility of challenge, recognition and enforcement and the application of principles of res judicata, preclusion and stare decisis.

The legal sources on which the work is based are listed meticulously and comprehensively in the last 400 pages and are divided into numerous Tables of commentaries; treatises and monographs; articles; statutes; arbitration rules; UN documents; an index of arbitral awards; a large index of court cases from all over the world; and a keyword index.

In the following, I will try to briefly summarise each chapter in consecutive order.

Chapter 1 provides an overview of the history and contemporary legal framework for international commercial arbitration. Born draws a detailed picture of the history of international arbitration, its key objectives, and outlines today's legal framework including international arbitration conventions, national arbitration legislation, institutional arbitration rules, international arbitration agreements and choice-of-law rules. The chapter also summarises leading theories on international arbitration. Finally, the chapter gives a brief summary of 
the main sources of information in the field of international commercial arbitration. This chapter alone provides an almost complete summary of all important aspects of contemporaneous arbitration. It can be used as a comprehensive introduction by interested students or practitioners who do not have to deal with specific issues.

The first chapter in Part I dealing with the arbitration agreement is Chapter 2, which is entitled the 'Legal Framework for International Arbitration Agreements'. It introduces the presumptive validity of international commercial arbitration agreements under contemporary international arbitration conventions and national legislation. It then addresses the definition of the term 'arbitration agreement', again under both international and national instruments, and examines additional jurisdictional requirements such as that the agreement relate to a 'commercial', 'international' and 'defined legal' relationship, as well as the term 'dispute'. It is noteworthy at this point already that the author offers his own critical analysis whenever appropriate, for example, when discussing how 'arbitration' should be defined, as opposed to other forms of dispute resolution, a question which is not only of an academic nature (pp. 252-254).

Ghapter 3 deals with the theory that an arbitration agreement is 'separable' or 'autonomous' from the underlying contract within which it is found. Born notes that this 'separability doctrine' should more accurately be referred to as the 'separability presumption'. He concludes that whatever its precise formulation, separability is undoubtedly of central significance in international commercial arbitration, because it has substantial practical, as well as analytical, importance, and has a number of closely-connected consequences relating to issues of choice of law, contractual validity and competence-competence. While in the author's view, the first two of the effects of the separability doctrine - the possible applicability of different legal rules and the possible validity of the arbitration agreement, notwithstanding defects in the underlying contract - play vital roles in ensuring the efficacy of the international arbitral process, there have been inconsistencies all over the globe and misunderstandings as to its further effects: In support of his opinion, Born offers extensive analysis of, among others, German, English, US, Swiss, French and various further authority, court and arbitral practice (p. 341 et seq.). He then emphasises that nothing can be gained from debates over the appropriate label ('autonomy' or 'separability') to be used in discussing international arbitration agreements. Rather, the arbitration clause remains closely connected to the parties' main contract and has an interrelated, supportive function. Born concludes that while the arbitration agreement should generally be 'separated' from the underlying contract for various purposes, it is never entirely or necessarily 'autonomous' or 'independent' from the underlying agreement (pp. 348-353 and 396-402). By offering his thorough analysis, Born demonstrates the precision with which he tackles difficult issues and reveals that many theories in international arbitration tend to blur the view of practitioners and thus to lead them to unsatisfactory results rather than to help them analyse a problem properly. This is only one of several parts of the book that make it unique in that it is detailed, precise and theoretically sophisticated, yet always written in accessible and easy to understand language. 
Chapter 4 on the choice of the law applicable to an international arbitration agreement begins with an introduction that makes every arbitration practitioner sigh in support: The topic has given rise to extensive commentary, and almost equally extensive confusion. Born's extended analysis sheds light into the confusion, which has been due in part to the difficulties associated with the separability doctrine. Moreover, different issues may be governed by different applicable laws (e.g. different laws may apply to issues of formal validity, capacity, substantive validity, assignment and waiver). Born describes the recent efforts to reduce these complexities, and the uncertainties that they produce, by legislators, authorities and national courts. He addresses the developments in particular in France, the United States and Switzerland, in applying international minimum standards to the substantive validity of arbitration agreements. But he does not stop there: on every issue which has not been resolved or addressed in a satisfying manner, he draws his own critical conclusions, mostly in the sections entitled 'Future Directions' (see e.g., p. 514 et seq. regarding choice of law in the context of formation and substantive validity of the arbitration agreement, or p. 523 regarding non-arbitrability). Look for these sections if you are interested in creative but still practicable solutions to your own problems!

The long Chapter 5 discusses the substantive legal issues arising in connection with the formation, validity and legality of international arbitration agreements, including the capacity of parties to enter into arbitration agreements, the formation of arbitration agreements, including standards of proof, consent and defects in consent, the substantive validity of international arbitration agreements, including issues of fraud, mistake, illegality, unconscionability, waiver and the like, and non-arbitrability, as well as the procedural requirements imposed by arbitration agreements and the effects of non-compliance with these requirements. Born notes that although parties frequently agree to arbitrate, they often reconsider that commitment when disputes arise, and instead seek to litigate their claims (or defences) in more familiar local courts. He then depicts the obvious tendency over the past century, evolving from a position of relative disfavour in some leading jurisdictions to one of essentially universal favour and affirmative encouragement. While all modern textbooks depart from this tendency as a fact, it is very helpful for the reader to learn more about how it developed in various jurisdictions and to which extent there are still differences. Particularly noteworthy are the author's conclusions (again entitled 'Future Directions') regarding the so-called non-arbitrability doctrine, which Born recommends to apply only restrictively, especially when arbitrability is to be examined in the context of recognition and enforcement (pp. 837-841, especially p. 840).

Chapter 6 dealing with the so-called doctrine of 'competence-competence' not only describes the content of this important theory, but also its historical development and current status. Finally, it addresses the procedural issues arising within the arbitral process itself from the arbitrators' exercise of their competence-competence. Although all developed national legal systems recognise competence-competence as a principle, Born shows that there is almost equally broad disagreement and uncertainty concerning the doctrine's precise scope and consequences: in 
particular, various national legal systems provide for the arbitrators to initially decide jurisdictional issues (subject to subsequent judicial review) while other legal systems permit initial judicial decisions on jurisdictional objections. Even more importantly, some legal regimes (such as Sweden and China) accord a tribunal's decision on its own jurisdiction no or virtually no deference, while other systems (such as France) accord such decisions extremely broad deference and binding effect. Yet other legal systems adopt various middle grounds (e.g. UNCITRAL Model Law, and the law of the United States, which is dealt with very extensively, and England), recognising the arbitrator's competence-competence, but permitting interlocutory judicial consideration of jurisdictional issues in limited circumstances. Born concludes that one should not use only historic formulae which may inevitably create confusion, but rather a neutral term, such as jurisdictional competence', which he believes would likely be more transparent and less likely to cause confusion. As in other contexts, a 'Future Directions' section provides a series of thoughtful proposals by the author (pp. 966-986).

Chapter 7 deals with the (positive and negative) effects and enforcement of international arbitration agreements, including the different mechanisms for enforcing them under leading legal systems, and the related subjects of anti-suit and anti-arbitration injunctions. These subjects, in particular the issue of how the courts of various jurisdictions deal with them, and their detailed analysis by the author who obviously has great expertise in the civil litigation aspects evolving around arbitration, makes the chapter invaluable for anyone interested in the interface between arbitration and court litigation. For lawyers such as the reviewer who have been raised in civil law systems, the section on anti-suit and anti-arbitration injunctions in various legal systems (pp. 1036-1046) is of particular interest.

Chapter 8 examines in detail the interpretation of international arbitration agreements, and describes the various rules of construction which are applied in different legal systems. Born takes a very critical position with regard to the practice of certain US and other courts which (in his opinion) have applied an unnecessary restrictive approach in determining the validity of an arbitration agreement rather than his proposed pro-arbitration presumption (pp. 1071$1072 ; 1081-1082$ ).

Chapter 9 deals with the parties to arbitration agreements. The author's analysis is important for the determination of which entities are bound by, and what entities may invoke, an international arbitration agreement. Born examines in 70 pages the various legal doctrines that have been used by authors and courts to give effect to arbitration agreements vis-à-vis entities that did not execute such agreements ('non-signatories'), including theories of agency, alter ego status (or veil piercing), 'group of companies', estoppel, guarantor relations, third party beneficiary rights, succession, assignment, assumption, and miscellaneous other grounds. The rich body of references to doctrine, court and arbitral practice allows the user of this book not only to understand these various (and not universally accepted) principles, but also to learn how they have been dealt with in a very heterogeneous manner by various courts and arbitral tribunals. This is 
the most complete analysis so far known to the reviewer within a textbook on international arbitration, and is particularly helpful in view of the fact that only very few statutory sources exist that sufficiently address these issues. The reader will find Born's clear opinions on every single one of these issues particularly helpful.

The first chapter in Part II regarding procedure is Chapter 10, which analyses the complex legal framework of international arbitration conventions and national arbitration legislation as they apply to international arbitral proceedings. It includes a detailed discussion of the concept of the 'seat' (or 'place') of arbitration, its legal consequences and effects, as well as the closely-related subject of the 'procedural law' governing international arbitration proceedings and the conflict of laws issues that arise in identifying the procedural law. The author shows (and understandingly deplores) that this legal framework is a subject of considerable complexity and occasional confusion. At the same time, Born demonstrates forcefully that such confusion can be clarified through careful attention to terminology and to appreciation of the continuing evolution of international and national instruments away from historical approaches towards the law governing international arbitral proceedings. The reader will note Born's proposed interpretation of the New York Convention, according to which the Convention's terms also impose international limits on the procedural requirements of the laws of the arbitral seat. In particular, according to the author, the Convention defines the role of national courts with exclusive reference to the annulment, recognition and enforcement of arbitral awards (pp. 1264-1265). This view corresponds to an expansive interpretation of the presumed party's will, according to which a far-reaching procedural autonomy should be granted to the parties with regard to the choice of rules to be applied to the arbitral procedure (pp. 1343-1346).

Chapter 11 deals with the selection, challenge and replacement of arbitrators. The delicate issue of independence and impartiality of arbitrators is analysed in refreshingly great detail (pp. 1458-1552), and illustrated by many famous and infamous cases. Although Born does not really reveal his own opinion on whether he leans towards the strict approach which is often associated with US or German decisions, or rather towards the more lenient approach known for the practice in the southern part of the world, the author offers a profound insight into the wide span of possible attitudes and the practice associated therewith, including, of course, a thorough analysis of the standard set by the IBA Guidelines on Conflicts of Interest which have sought to reconcile the widely diverging positions.

In the following three relatively short Chapters 12 to 14 , Born examines the rights and duties of arbitrators (including some important details on the contractual aspects of such duties), deals with the selection of the arbitral seat; and analyses the procedural conduct of international commercial arbitration.

Chapter 15 on disclosure and discovery is important both for lawyers who are familiar with US-style litigation practices and civil law-trained lawyers who are not. Born first describes the recent (and increasing) suggestions that disclosure and discovery are modern innovations, which are in tension with at least some aspects of the arbitral process. While there can be no doubt, in his mind, that the existence of power on the part of the arbitral tribunal to require the parties to 
produce documentary or other materials, is relevant and important to resolving the matters in dispute, he describes the widely different views with regard to the existence and scope of disclosure. Finally, he analyses the developing international practice and guidelines which reflect an emerging consensus on the general value of disclosure in the arbitral process and on the appropriate scope and procedures for disclosure, as forcefully demonstrated by the ever-growing importance of the IBA Rules on the Taking of Evidence (pp. 1792-1794). Born further shows that the relevant issue in each case is the scope of the materials that must be produced, and that disagreement over terminology is a poor means of addressing or resolving such questions.

Chapter 16 addresses provisional or interim measures which are designed to protect parties or property during the pendency of international arbitral proceedings. Born describes and examines the recent development that both international instruments and national statutes have removed many of the historic limits on the powers of arbitrators to grant such measures (p. 1951 et seq.), and arbitral tribunals have demonstrated their increased willingness to make use of such powers (pp. 1975-1976). These developments, which have been reflected in the most recent revisions of the UNCITRAL Model Law (pp. 1952-1954), have made provisional measures much more important in contemporary international arbitration, both as a means of protecting the parties' legitimate interests and as tactical measures aimed at exerting pressure on adverse parties. Again, the author not only discusses the extent to which international arbitral tribunals are authorised to grant provisional relief and the circumstances in which they will be willing to do so. He also shows in great detail the extent to which national courts have been - and should be - prepared to enforce such provisional measures ordered by international arbitral tribunals, and in what instances national courts have granted (and should grant) provisional relief in aid of an international arbitration (p. 2028 et seq.). In a noteworthy personal opinion, Born again requires that Article II of the New York Convention should be read to require (rather than to restrict) such relief (p. 2038, with further references).

Chapter 17 deals with consolidation, joinder and intervention. These issues can raise significant problems with respect to the appointment of arbitrators and composition of the tribunal. They have gained much importance in recent years. The author shows that conflicting considerations may apply in this regard, and the way both national courts and arbitral tribunals (as well as arbitral institutions) have struggled to reconcile these considerations. They are particularly important in multiparty disputes. Here again, Born proposes to apply a sound proarbitration interpretation when deciding on these issues, but to respect the parties' expressed will (such as in situations where differing dispute resolution provisions have been chosen for different contracts, p. 2085).

A very careful Chapter 18 on the choice of substantive law complements Chapter 4 on the choice of law applicable to the arbitration agreement, with which it should not be confused. In one of his noteworthy 'Future Directions', Born argues, in the absence of choice-of-law agreements by the parties, for the application of the choice-of-law rules at the seat of the arbitration in the event a 
true conflict exists, and proposes a ladder of conflict rules which should reflect the parties' desire for predictability, certainty and neutrality of the substantive law of their dispute (pp. 2140-2141). As others, Born is critical of the application of the so-called 'lex mercatoria' (p. 2143 et seq.). Important comments are devoted to the issue of mandatory laws and public policy, a recurrent and still growing problem not only in theory, but in the daily practice of arbitrators (pp. 2170-2203).

Chapter 19 is devoted to confidentiality and privacy, a subject which has been vigorously debated in recent years. The author establishes the importance of distinguishing between the two terms, and deplores the unsatisfactory status quo. $\mathrm{He}$ analyses the recent developments that have pointed strongly in the direction of increased recognition of confidentiality obligations, and offers his own conclusions, in particular that there is a presumption of an (implied) confidentiality obligation, which may be overcome only by contrary agreement (either express or implied), but that the implied confidentiality obligation should not be regarded as absolute nor extend invariably to all elements of the arbitral process (pp. 22802287).

The short Chapter 20 deals with legal representation and professional conduct in international arbitration, and joins those who have proposed an international code of conduct for counsel in international arbitration (pp. 2324-2326).

Part III on 'Awards' begins with Chapter 21, in which the legal framework regarding the effects of international arbitral awards is analysed. Born summarises the sources of national and international law applicable to the making, annulling, correcting, confirming, recognising and enforcing of such awards. While he recognises that the overall effect of the international and national instruments is to establish a strongly 'pro-enforcement' legal regime, he also demonstrates that the practice of courts varies widely as regards the interpretation of the grounds, and even more, of the defences which are aimed at preventing such recognition and enforcement. The chapter must be read in conjunction with Chapter 25 which analyses the grounds for recognition and enforcement. Both chapters, especially the detailed section analysing the grounds for refusing recognition and enforcement under the New York Convention (pp. 2730-2878), are particularly helpful in view of the fact that to this point, comprehensive and truly comparative commentaries on the New York Convention, the most important legal source in this context, have been scarce (apart from Albert Jan Van den Berg's book ${ }^{10}$ which, however, has not been edited for almost three decades). Also, Born offers his own view on how to cope with Hilmarton and Chromalloy and similar situations in the future (p. 2691 et seq.).

Chapter 22 deals with the form and contents of awards, and Chapter 23 is devoted to their correction, interpretation and supplementation. Born's differentiation of the 'functus officio' doctrine is particularly noteworthy (pp. 2519-2520): he concludes that there should be a presumption that parties intend the arbitrators to become functus officio following the making of an award, and that the limited

10 Albert Jan van den Berg, The New York Arbitration Convention of 1958 (1981). 
exceptions which are essential to the fairness of the arbitral process even apply in the absence of legislative provisions.

Chapter 24 on the annulment of awards first examines the grounds which are available for annulling awards, in particular under national arbitration legislation, and then examines the consequences of a judicial decision annulling them. While most developed national arbitration regimes have adopted broadly similar approaches in that regard, Born's extensive analysis of the relevant statutory grounds such as, in particular, those listed by article 34 of the UNCITRAL Model Law and national court decisions demonstrate that both their interpretation and their effects lead to highly diverging results. Born takes a rather diplomatic position regarding the question of how to deal with the issue whether the merits of arbitral awards should be subject to judicial review beyond international public policy, and proposes a compromise between the widely diverging positions (pp. 2651 et seq., 2654-2655).

The concluding Chapter 26 examines the role of preclusion and related principles, including res judicata, collateral estoppel and stare decisis, in international arbitration. It examines the preclusive effect of an arbitral award in subsequent national court litigation, and also the preclusive effect of national court judgments and arbitral awards in subsequent international arbitral proceedings. Last, but not least, the author discusses the application of lis pendens principles, and the role of precedent and the doctrine of stare decisis. More so than other treatises in the field, Born's analysis illustrates the importance of res judicata in international arbitration in great detail. Again, he proposes an interpretation of Article II (not only Article III) of the New York Convention with the purpose to include a preclusive effect of arbitration agreements, because states should not be free to allow relitigation of disputes without regard to the results of prior arbitral proceedings (p. 2890). While it may be questionable that the time is ripe for unification in this regard, the author's broad comparative analysis helps to better understand the different approaches worldwide. Based on various experiences, including the Swiss Federal Tribunal in the famous Fomento case (which has been overruled by new legislation in the meantime), ${ }^{11}$ Born concludes that the lis pendens doctrine does not provide grounds, where a jurisdictional objection is pending in a national court (and particularly a court outside the arbitral seat), for imposing any absolute rule requiring an arbitral tribunal to suspend its own consideration of jurisdictional issues (pp. 2942-2943).

In a book of this length, it may sound almost pedantic to address certain errors which have escaped the author (but may easily be dispensed with by the next edition of the book):

- Certain readers who are used to textbooks which are structured in the way Pascal's triangle was, i.e. consequently using identical logical elements, may have to adapt to this book, because one cannot always easily distinguish

11 Fomento de Construcciones y Contrates SA v. Colon Container Terminal SA, Judgment of 14 May 2001, DFT 127 III 279 (Swiss Federal Tribunal). 
between description and analysis, and between outlook and interpretation of the status quo. However, the very detailed indices at the end of the book will help even pedantic logicians and sophists find their way.

- Page 126 is missing and instead, p. 122 is offered twice. This may hurt the feelings of readers from Switzerland such as the reviewer and those particularly interested in the Swiss practice, in addition to the fact that the growing number of arbitral proceedings administrated by the Swiss Chambers, which has long surpassed those of other institutions, is not listed in the charts displayed in Chapter 1 (p. 69).

- Another printing error occurred on page $463 / 465$ on the application of Art. VI (1)(a) of the New York Convention. It appears that the publisher Kluwer has sent out errata and is reprinting. The Swiss reader is comforted that he or she is not the only target of the printing devil.

- Obviously, there are a few typographical and other inadvertent mistakes such as the incorrect citation of the famous Revue de L'arbitrage which has been addressed as 'Revue Arbitrage' (p. 190).

To conclude, Born's monumental work is distinguished by its remarkable comprehensiveness, and its both careful and yet critical analysis of international instruments, legislation, doctrinal authority, court decisions and arbitral awards from all over the world. International Commercial Arbitration goes further, developing from these disparate sources, and from Born's interpretation of the New York Convention, a cohesive body of international arbitration law. As the author correctly states, 'national courts not only have but should consider one another's decisions in resolving issues concerning international arbitration. By considering the treatment of international arbitration in other jurisdictions, and the policies which inspire that treatment, national legislatures and courts can draw inspiration for resolving comparable problems. Indeed, only by taking into account how the various aspects of the international arbitral process are analysed and regulated in different jurisdictions is it possible for courts in any particular state to play their optimal role in that process. This involves considerations of uniformity - where the harmonization of national laws in different jurisdictions can produce fairer and more efficient results - as well as the ongoing reform of the legal frameworks for international arbitration - where national courts and legislatures progressively develop superior solutions to the problems that arise in the arbitral process'.

In summary, International Commercial Arbitration is a seminal study in many respects:

- It is comprehensive, takes a global look, introduces the reader softly, then enters into all the details both practitioners and, yes, even academics would wish to be addressed, including an impressive body of references to authority and practice both by courts and published awards from all over the world.

- Whenever a problem has not been addressed sufficiently by the community, either because it has not yet been adequately identified or not been solved 
in a satisfying way, Born offers his own critical opinion, denominated as 'Future Directions', which is almost invariably based on the presumptive intent of parties to international commercial transactions to wish for an efficient and fair resolution of their dispute. In doing that, he does not stop at analysing the status quo but offers refreshingly consistent solutions for legislation, interpretation and development of the legal instruments available.

- Despite the considerable length and complexity of Born's analysis, one of the ambitious goals of the book is to be clear, direct and accessible. 'Like most things, the arbitral process works better, and its problems are more readily addressed, when it is clearly described. Every effort has been made to avoid obscurity, and instead to present matters clearly and simply so they can be understood and debated.' This reviewer believes that, despite its length, the book has reached that goal.

- Most ambitiously, International Commercial Arbitration develops a comprehensive interpretation of the New York Convention, as providing a 'constitutional' framework for international commercial arbitration. Drawing on sources from around the world, and on a penetrating analysis of the Convention, Born's work is ground-breaking in its exploration of the legal framework within which international arbitration functions and it will play a substantial role in the development of international arbitration worldwide.

It goes without saying that to acquire the book is mandatory for everyone dealing with international arbitration. Not consulting it will soon amount to an unforgivable mistake on the part of practitioners and academics alike.

\section{Campbell McLachlan $Q C^{* * * *}$}

Gary Born's magisterial new work, International Commercial Arbitration, published in two volumes, represents, in the range and depth of its coverage, and in the rigour and perception of its analysis, the most complete exposition of the law of international commercial arbitration ever available. Yet, perhaps the most remarkable thing about this book is what it represents in terms of a coming of age of the field of international commercial arbitration, such that a book of this kind could be written at all.

Born states modestly in his 'Introduction' that his treatise 'is intended to be clear, direct and accessible', and so it is. Indeed, devotees of Gary Born's earlier works, starting with his ground-breaking, now classic case-book International Civil

\footnotetext{
**** Victoria University of Wellington; Bankside Chambers (Auckland) and Essex Court Chambers (London); Member, ICSID Panel of Arbitrators; the reviewer is author (with Shore and Weiniger) of International Investment Arbitration: Substantive Principles (2007; paperback edn 2008), and has editorial responsibility (with Collins) for the Arbitration section of Dicey, Morris and Collins on the Conflict of Laws (14th edn, 2006).
} 